\title{
Scores Used in Sore Throat
}

\section{Serdar Özdemir}

Department of Emergency Medicine, University of Health Sciences Umraniye Training and Research Hospital, Istanbul, Turkey

Sore throat is a common reason for applying to emergency services and primary health care services for medical care and examination. Every year, approximately $10 \%$ of the people apply to primary health care services because of sore throat. ${ }^{[1]}$ The majority of sore throat due to infection arises from viruses. ${ }^{[1]}$

In January 2014, it was reported that 6254 (37.5\%) patients admitted to the emergency department with a total of 23424 admissions were diagnosed with upper respiratory tract infection. Also, this study showed that the antibiotic was prescribed to $63.5 \%$ of the patients. ${ }^{[2]}$

In 1981, Centor et al. defined four criteria as follows:a history of fever, painful anterior cervical lymphadenopathy, presence of exudate on tonsils and absence of cough. This score system is called Centor Criteria. Their study population consisted of emergency department patients over the age of $15 .^{[3]}$

Mclsaac et al. added age as criteria to Centor Criteria in 1991. They suggested that the score should be calculated by adding 1 to individuals under 15 years of age and subtracting 1 from individuals over 45 years of age. As a result of their study, they recommended that patients receiving 0-1 points do not need antibiotherapy, patients receiving 2-3 points should receive culture, antibiotics should be started according to the result, and patients receiving 4-5 points should start antibiotics without waiting for culture results. ${ }^{[4]}$ This score system is named as Mc Isaac score ormodified Centor scorein the literature.

After these studies, although the scores were accepted by the Centers for Disease Control and Prevention, the scores were not accepted by the clinicians. Fine et al. analyzed the data collected from 206.870 patients aged three years and over in 2012 to establish and validate scores. The primer outcome measures, scores of Centor and Mclsaac and group A streptococcus positivity were evaluated. This study confirmed the results of other studies. ${ }^{[5]}$

Mistık et al. recommended a new scoring system for detecting viral etiology in a study conducted in Turkey. The history, symptoms and physical examination findings obtained from the patient are used in Mistık Score. If the score is 5 or more, the rate of viral sore throat is 82.2\%. However, a low Mistık Score is not enough to indicate a bacterial infection. By using the Mıstık Score, $30.7 \%$ of unnecessary antibiotic use can be prevented. ${ }^{[6]}$

In January 2017, The Ministry of Health-Turkey recommended that the use of the modified Centor score to determine the need for antibiotics in patients with acute upper respiratory tract infection. They suggested that this score could be calculated with the software of Family Physician Information System and Hospital Information Management System. ${ }^{[7]}$

In the United Kingdom, in 2017, "Decision rule for the Symptoms and Complications of Acute 
Red Throat in Everyday practice-DESCARTE" study investigated the effects of delayed antibiotic use on symptom duration. Patients presenting with acute sore throat were given a form and were asked to follow their symptoms and mark the form. One thousand five hundred twelve forms were evaluated. The findings showed that delayed antibiotic strategy and emergency antibiotic strategy in the routine treatment of adults with sore throat provide similar symptomatic benefits. ${ }^{[8]}$

\section{REFERENCES}

1. Spinks A, Glasziou PP, Del Mar CB. Antibiotics for sore throat. Cochrane Database Syst Rev 2013;2013(11):CD000023.

2. Ozdemir S, Ozturk TC, Metiner Y, Ak R, Ocal O. Evaluation of the prescriptions written for upper respiratory tract infections. North Clin Istanb 2015;2(2):107-14.

3. Centor RM, Witherspoon JM, Dalton HP, Brody CE, Link K. The diagnosis of strep throat in adults in the emergency room. Med Decis Making 1981;1(3):239-46.

4. Mclsaac WJ, White D, Tannenbaum D, Low DE. A clinical score to reduce unnecessary antibiotic use in patients with sore throat. CMAJ 1998;158(1):75-83.

5. Fine $A M$, Nizet $V$, Mandl KD. Large-scale validation of the Centor and Mclsaac scores to predict group A streptococcal pharyngitis. Arch Intern Med 2012;172(11):84752.

6. Mistik S, Gokahmetoglu S, Balci E, Onuk FA. Sore throat in primary care project: a clinical score to diagnose viral sore throat. Fam Pract 2015;32(3):263-8.

7. Akılcı Antibiyotik Kuralları. Available at: https://dosyamerkez.saglik.gov.tr/Eklenti/6418,akilci-antibiyotik-kurallariustyazipdf.pdf. Accessed Mar 11, 2020.

8. Moore M, Stuart B, Hobbs FR, Butler CC, Hay AD, Campbell J, et al. Symptom response to antibiotic prescribing strategies in acute sore throat in adults: the DESCARTE prospective cohort study in UK general practice. $\mathrm{Br} J$ Gen Pract 2017;67(662):e634-e42. 